\title{
Students' Perception of The Blended Learning Model Implementation in Vocational Field at Home Economics Department Semarang State University
}

\author{
Pudji Astuti ${ }^{1}$, Asih Kuswardinah ${ }^{1}$, Wahyuningsih ${ }^{1}$, Dyah Nurani Setyaningsih ${ }^{1}$, Mediati Fajri \\ Putri $^{1}$, Sita Nurmasitah ${ }^{1}$, Agus Khamid ${ }^{2}$, Sekar Wangi Dewi Pramita ${ }^{2}$ \\ \{pudjiastuti@mail.unnes.ac.id\} \\ ${ }^{1}$ Department of Home Economics, Faculty of Engineering, \\ Semarang State University, Semarang Indonesia \\ ${ }^{2}$ Student of Department of Home Economics, Faculty of Engineering, \\ Semarang State University, Semarang Indonesia
}

\begin{abstract}
Human resources in the industrial revolution era 4.0 are expected to master and to be able taking advantage of digital literacy. Graduates from the Department of Home Economics (PKK) are prospective vocational teachers who will be the agents of reformation to habituate the digital literacy to the students. Because of that reason, the learning activities in the Department of Home Economics is using a blended learning model. The data analysis technique used in this study was descriptive percentages. Statement items related to facilities, motivation, material and tasks, time and cost, independence, communication/ interaction, and responses to tasks with categories ranging from strongly disagree to strongly agree were used as the data collection instrument. The results show that the overall perception of students as prospective vocational teacher was "agree" with the percentage of $53.5 \%$, while the smallest was $0 \%$ in the category of "strongly disagree", the second largest was $34 \%$ "less agree". Then $10 \%$ "strongly agree" and $1.9 \%$ "disagree.".
\end{abstract}

Keywords: implementation of blended learning, student's perseption, home economic department.

\section{Introduction}

The industrial revolution has evolved to the industrial revolution 4.0. The industrial revolution 4.0 is not only faced by the world trade but also the world of education. Education must provide creative human resources using digital technology. Higher education institution must develop a quality culture in order to have global level competitiveness. The world of education in learning activities not only focuses on reading data computation competencies but also complements data literacy, technology literacy, and human literacy. Data literacy is related to the ability to read, analyze, and make conclusions of thinking based on the data and information obtained. In technology literacy related to the workings of machines, the application 
of technology to produce maximum results. While human literacy is related to the ability to communicate, collaborate, think critically, creatively, and innovatively.

In higher education institutions, the industrial revolution 4.0 is, among others, addressed with programs and service models that provide more or use digital technology (online) for example the learning activities using online systems which then develop massive open online course infrastructure. Thus Universitas Negeri Semarang (UNNES), developing curriculum that is anticipatory and adaptive so that one of the policies in learning is applying the blended learning model, using Elena, which encourages students to learn independently. In addition to the curriculum, there is a course on Digital Literacy and Humanity.

The curriculum in the Department of Home Economics (PKK) contains practice and theory courses. The distribution of courses in each semester is adjusted to the competencies, lecturers, and facilities of the department. Learning activities are usually carried out face-to-face model and with the assignment of presentations, reviewing articles, and making papers that have been done but the results are not yet satisfied. In the future, the graduates as prospective vocational teachers must have the ability shown in aspects of attitudes, knowledge, and skills. In other activities, approximately $15 \%$ of students are involved in student organizational activities such as HIMPRO, ENERC, RISTEK, BEM, and others. The achievements made by PKK Department students are low, less than $2 \%$ who have non-academic achievements. Students in the PKK Department come from various provinces, mostly from the Central Java region, which is spread from several districts. According to the previous education level, most of the students are graduated from high schools and around $26.2 \%$ of vocational high schools.

The application of the blended learning model is to strengthen the ability of students to face the work era in the future as professional vocational teachers. Learning activities with blended learning models are learning activities that combine face-to-face and online learning. According to Bonk and Graham [1] blended learning is the combination of instruction from two historically separate models of teaching and learning: Traditional learning systems and distributed learning systems. It emphasizes the central role of computer-based technologies in blended learning.

Blended learning gives students the opportunity to determine when to start and when to finish, and which parts of the module or material will be studied first. If there is material that is not yet understood by students, it can communicate according to the specified media.

Blended Learning model uses online media learning and traditional learning, namely face to face. According to Thorne [2] blended learning is learning that combines multimedia technology in the form of a CD-Room, video streaming, virtual classroom, email, conference telephone, and video streaming with traditional learning that is face-to-face learning. Meanwhile, Semier in Husamah [3] stated that blended learning combines online learning, faceto-face, and real-world practice. Blended Learning uses an approach that empowers various sources of information.

In general, this research was conducted to determine the perceptions of students as perspective vocational teachers on the implementation of blended learning model. It is to explore the students' perception in using blended learning models.

\section{Research Method}

The study used a qualitative approach; analyzing and describing the perspectives of students as prospective vocational teachers towards a blended learning model. The sample in 
this study was taken by means of a purposive random sampling of 210 students who filled out the questionnaire by following the form of a Likert scale. This scale measures students' perceptions on the implementation of the blended learning model with positive answers located on the left and negative answers on the right. Acceptance or rejection is stated in the agreement, starting from "strongly agree" with a score of 5, "agree" with a score of 4, "less agree" with a score of 3, "disagree" with a score of 2 and "strongly disagree" with a score of 1.

The data analysis technique used in this study is descriptive percentages that describe findings in the perception of blended learning model with logical statements about facilities, motivation, material and tasks, time and cost, independence, communication / interaction, and response to tasks.

\section{Result and Discussion}

Learning is a process with the series of actions between educators and students on the reciprocal relationships that take place in educational conditions to achieve learning objectives. In learning activities, there is a process of acquiring knowledge, mastery of skills, and the formation of attitudes in students. Students have a high role in learning success that is supported by a learning environment such as facilities, materials, learning models used, and others. As the prospective vocational teachers, the graduates of PKK Department must have the ability aspects of professional attitudes, knowledge, and skills to be ready to work in their fields. Through the learning activities of the blended learning model students will interact with learning resources and learning environments that occur inside and outside the classroom.

The results showed that students' perceptions on the implementation of the blended learning model are presented in table 1.

Table 1. Total Data

\begin{tabular}{rcc}
\hline Respondent & Percentage & Category \\
\hline 0 & 0 & Strongly Disagree \\
\hline 4 & 1.9 & Disagree \\
\hline 73 & 34.8 & Less Agree \\
\hline 112 & 53.5 & Agree \\
\hline 21 & 10 & Strongly Agree \\
\hline
\end{tabular}

Most of the respondents stated that they are "agree" $53.5 \%$, then $34.76 \%$ of respondents "less agree", $10 \%$ of respondents "strongly agree", and $1.9 \%$ "disagree". It shows that the implementation of the blended learning model supports the learning activities undertaken by students to achieve their abilities as the prospective vocational teachers.

The detailed research data on each item is presented in a row as follows, starting from facilities, motivation, material and tasks, time and cost, independence, communication and interaction, and response to tasks.

\subsection{Fcilities}

The facility is a support facility used in blended learning from students and from the campus. The results of the research are presented in table 2 . 
Table 2. Facilities.

\begin{tabular}{ccc}
\hline Respondent & Percentage & Category \\
\hline 0 & 0 & Strongly Disagree \\
\hline 12 & 2.38 & Disagree \\
\hline 73 & 34.76 & Less Agree \\
\hline 95 & 45.24 & Agree \\
\hline 40 & 14.29 & Strongly Agree \\
\hline
\end{tabular}

The research data in table 2 shows that most students stated "agree" with a percentage of $45.24 \%$. Then a number of $34.76 \%$ of respondents expressed "less agree", then in a row $14.29 \%$ of respondents stated "strongly agree" and $2.38 \%$ of respondents said "disagree".

Facilities are very important in implementing the blended learning model. Support facilities provided by the campus and students themselves make learning activities using the blended learning model run well.

The internet network at UNNES uses a bandwidth of $1.6 \mathrm{~GB}$ supported by optical fiber connections between faculties. Hotspots are provided in the classrooms, gazebo, which are installed electricity lines around the PKK Department and the Faculty of Engineering and they can be used by the students. This provides convenience and comfort to the students in accessing the internet related to learning activities and doing assignments.

In addition, students also use their own facilities, such as laptops and smartphones in accessing the internet in blended learning activities. This shows that facilities related to the blended learning model is generally good.

\subsection{Motivation}

Motivation is the process of encouraging. Related to learning, motivation is an activity that can provide enthusiasm for learning. The results of the study are presented in table 3 .

Table 3. Motivation

\begin{tabular}{ccl}
\hline Respondent & Percentage & \multicolumn{1}{c}{ Category } \\
\hline 2 & 0.95 & Strongly Disagree \\
\hline 16 & 7.62 & Disagree \\
\hline 69 & 32.9 & Less Agree \\
\hline 91 & 43.3 & Agree \\
\hline 32 & 15.2 & Strongly Agree \\
\hline
\end{tabular}

Table 3 shows that $43.3 \%$ of respondents "agree". Other responses from students are $32.9 \%$ "less agree", then 15\% "strongly agree", 7.62\% "disagree" and $0.95 \%$ "strongly disagree".

In learning activities, motivation is needed. Motivation for learning can come from outside and from within individuals. Most students' perceptions of learning activities using the blended learning model mostly agree that blended learning can motivate learning. This is in line with research conducted by Handaru [4] that there is an increase in student motivation due to the application of blended learning models by 11.705 . The content presented by the lecturer in 
uploading material can motivate students to learn. Likewise, research by Farihah [5] stated that the blended learning model has an influence on the motivation and learning outcomes of class $\mathrm{X}$ students of SMA N 1 Pitumpapua.

\subsection{Material and Tasks}

The students learn the material and do the tasks from the lecturer.

Table 4. Material and Tasks

\begin{tabular}{ccl}
\hline Respondent & Percentage & \multicolumn{1}{c}{ Category } \\
\hline 2 & 1.43 & Strongly Disagree \\
\hline 8 & 3.81 & Disagree \\
\hline 72 & 34.3 & Less Agree \\
\hline 90 & 42.9 & Agree \\
\hline 38 & 18.1 & Strongly Agree \\
\hline
\end{tabular}

In the content of material and tasks, 42.9 respondents "agree". Others said that they "less agree" $34.3 \%$, then $18.1 \%$ "strongly agree", $3.81 \%$ said they "disagree" and at least $1.43 \%$ "strongly disagree".

Most of the students' perceptions on learning activities using blended learning stated that they agree with the material presented that is systematic and easy to understand. Material that is systematic and easy to understand makes it easy for students to learn. In addition, students determine themselves when to start and when to finish within a certain time limit. Students' lack of understanding of the material and assignments can be communicated with the lecturer. The results of this study differ from the results of Nuryansyah's research [6] that a number of 33.33\% said "disagree". The uploaded material was difficult to understand and students kept asking questions until they understand. According to the students, it would be difficult to do online.

\subsection{Time and Cost}

The time and cost means students have perceptions about the efficacy of using blended learning models.

Table 5. Time and Cost

\begin{tabular}{ccl}
\hline Respondent & Percentage & \multicolumn{1}{c}{ Category } \\
\hline 2 & 0.95 & Strongly Disagree \\
\hline 10 & 4.76 & Disagree \\
\hline 49 & 23.3 & Less Agree \\
\hline 88 & 41.9 & Agree \\
\hline 61 & 29 & Strongly Agree \\
\hline
\end{tabular}


Table 5 shows about the time and cost data, $41.9 \%$ of respondents "agree", $29 \%$ stated that they "strongly disagree" then $23.3 \%$ of respondents said they "less agree" and another $4.76 \%$ of respondents said they "disagree". The smallest number is $0.95 \%$ of respondents who "strongly disagree".

The applied blended leaning model makes the students no longer need to come to campus because students can learn and do it anywhere, so the students have more optimal time. Scheduled time can be used to do other things related to academic and non-academic activities. The students have more time to explore their potential to improve their abilities, where later after graduation they will become professional vocational teacher candidates, so they must study a lot on campus and off campus. In addition, students no longer need to collect assignments in the form of hard copies or do not come to campus to collect assignments so that students can save the costs.

\subsection{Indenpendence}

According to Tirtaraharja [7] independence in learning is learning activities that are driven by the will from within, their own choice, and their own responsibilities from learning. Learning independence is very necessary so that they have the responsibility in organizing and disciplining themselves in completing their assignments. In learning activities using the blended learning model, students have the will to learn even if they are not accompanied by a lecturer.

Table 6. Independence

\begin{tabular}{rcl}
\hline Respondent & Percentage & \multicolumn{1}{c}{ Category } \\
\hline 1 & 0.48 & Strongly Disagree \\
\hline 8 & 3.81 & Disagree \\
\hline 62 & 29.5 & Less Agree \\
\hline 105 & 50 & Agree \\
\hline 34 & 16.2 & Strongly Agree \\
\hline
\end{tabular}

In table 6 , a number of $50 \%$ of respondents "agree" that the implementation of the learning model of blended learning in has the effect of independence in learning, this is the largest percentage. Then, $29.5 \%$ of respondents expressed "less agree", $16.2 \%$ of respondents expressed "strongly agree", and $3.81 \%$ of respondents stated "disagree", while the smallest presentation of $0.48 \%$ of respondents stated "strongly disagree".

In the implementation of the blended learning model, $50 \%$ of the students stated agree. The blended learning model makes students able to learn independently. The online assignments or questions given by lecturers will guide students to be able to study independently. The students learn to manage time for academic activities and other supporting activities. Through blended learning, the students will find their own alternative answers which then determine the correct and correct answers. Husamah stated that students are free to manage the study independently which are available on line. Likewise, according to Aynur Gecer [8] students will be responsible, active, and work hard in participating in learning activities using the blended learning model. It will create the independence of student learning. The students are aware of their responsibilities in the learning environment using blended learning, where they access the internet to obtain material and development. The results of the study conducted by Aynur Gecer, found that students were aware of their responsibilities, they were active and worked hard in participating in learning activities of the blended learning model. In a study conducted by 
Shamsi S. Bawaneh [9], there was a positive relationship between the number of online files seen by students, the number of online discussion messages and their performance. Similarly, the results of research by Mukaddes Erdem and Pinar Nuhglu [10], the students have quite positive opinions on blended learning and its implementation and Facebook can be the right tools to communicate and interact. In another study conducted by Yunika Lestari et al [11], it was said that blended learning model can increase student learning independence higher than students taught by ordinary learning.

\subsection{Communication and Interaction}

Communication and interaction between students and lecturers can be done face-to-face or online. Communication between students and lecturers is an important thing to do in the learning process. What the lecturer wants related to the learning objectives will be conveyed to the students. The results of the research are presented in table 7.

Table 7. Communication/Interaction

\begin{tabular}{ccl}
\hline Respondent & Percentage & \multicolumn{1}{c}{ Category } \\
\hline 1 & 0.95 & Strongly Disagree \\
\hline 21 & 10 & Disagree \\
\hline 64 & 30.5 & Less Agree \\
\hline 94 & 44.8 & Agree \\
\hline 30 & 14.3 & Strongly Agree \\
\hline
\end{tabular}

In table 7 , the largest percentage is $44.8 \%$ of respondents "agree". The smallest percentage is $0.95 \%$ of respondents who "strongly disagree". Next, $30.5 \%$ of respondents said they "less agree", then $14.3 \%$ of respondents said they "strongly agree", then $10 \%$ of respondents said they "disagree".

Interaction in the learning process is very important, both between students and students and between lecturers and students. Well established interaction will facilitate the students in learning. Based on the result, the students feel more comfortable communicating and interacting with students and with lecturers. Although they are not face to face, they can communicate and interact with students and lecturers in broader time and opportunities. Moreover, the students still feel the presence of lecturers, although not directly. The students feel more comfortable expressing questions and opinions than directly. Sometimes the students cannot express things directly, so they prefer doing blended learning. It is in line with the research by Nuryansyah and Lestanto, which states that $57.41 \%$ of students agree that online lectures make it easier to interact with lecturers.

\subsection{Response to Tasks}

The students' response to the task are presented in table 8 as follows.

Table 8. Response to Tasks 


\begin{tabular}{ccl}
\hline Respondent & Percentage & \multicolumn{1}{c}{ Category } \\
\hline 5 & 2.38 & Strongly Disagree \\
\hline 20 & 9.52 & Disagree \\
\hline 85 & 40.5 & Less Agree \\
\hline 63 & 30 & Agree \\
\hline 36 & 17.1 & Strongly Agree \\
\hline
\end{tabular}

In table $8,40.5 \%$ respondents expressed "less agree". The small percentage of $2.38 \%$ of respondents stated "strongly disagree". Other $30 \%$ said they "agree" and $17.1 \%$ said they "strongly agree" and $9.52 \%$ of respondents said they "disagree".

In response to tasks, $40.5 \%$ of the students stated that they "less agree" with statements preferring to respond to questions or tasks directly compared to online. It means that students have a good perception of the uploaded questions or tasks. Students have time and opportunity to prepare materials to do the tasks or answer the questions. The results of this study are not in line with the results of research by Nuryansyah Adijaya and Lestanto, which is $50 \%$ of the respondents "agree" that students prefer to respond to questions directly rather than online. It can be due to the lack of available facilities, so that it will experience difficulties when accessing it.

\section{Conclusion and Suggestion}

\subsection{Conclusion}

The results of the research shows that students have a good perception on the implementation of the blended learning model, 53.5\% responded "agree". The existing lectures are theoretical and practical subjects. In online lectures, the material is selected accordingly in the form of videos, PPT, or documents along with the assignments that must be done by the students. Lecturers still provide the necessary feedback and advice so that communication and interaction between students and lecturers remain well established and the most important thing is the learning objectives are achieved. So, the blended learning model is well implemented in PKK Department.

\subsection{Suggestion}

Although the overall students' stated "agree in the implementation of blended learning, the facilities still need to be improved. For example the use of computer laboratories not only for scheduled learning activities but also can be used for completing lecture assignments outside of the class hours.

\section{References}

[1] Graham, C. R : Blended learning systems: Definition, current trends, and future directions. Dalam C. J. Bonk \& C. R. Graham (Eds), The Handbook of blended learning: Global perspectives, local designs (pp. 3-21). San Francisco, CA: John Wiley \& Sons, Inc. (2006). 
[2] Thorne, K. : Blended Learning: How to Integrate online and traditional learning, London: Kogan (2003).

[3] .Husamah : Pembelajaran Bauran (Blended Learning). Jakarta : Hasil Pustak (2013).

[4] Handaru jati : The Effescts of Blended Learning Model On The Student's Motivation an understanding On the Subject Of Algaritms nad Programming. Jurnal : Pendidikan Vokasi Vol 5, Nomor 1, Februari 2015 (2015)

[5] Farihah : Pengaruh Model Pembelajaran Blended Learning Terhadap Motivasi dan Hasil Belajar Siswa Kelas X SMA Negeri 1 Pitumpanua Kab.Wajo. Jurnal : Chemika Vol. 17 Nomor 2 desember 2017, 83 - 93 (2016)

[6] Nuryansyah Adijaya dan Lestanto P. S. : Persepsi mahasiswa Dalam Pembelajaran On line :

[7] jurnal Wanastra vol. 10. No 2 (2018) 105 - 110 (2018)

[8] Tirtarahardja Umar : Pengantar Pendidikan. Rineka Cipta (2005)

[9].Aynur Gecer Lecturer-Student Communication in Blended Learning Environments. Jurnal Educational Sciences: Theory and Practice, Vol 13 No. 1, Page 362-367 : (2013)

[10] Shamsi S. Bawaneh : The Effects of Blended Learning Approach on Student' Performance: Evidence from a Computerized Accounting Course. Intenational Journal of Humanities and Social Science Vol. No. 6. June 2011 (2011)

[11] Mukaddes Erdem dan Pinar Nuhoglu : Student'opinions on Facebook Suported Blended Learning Environment. Jurnal :The Turkish Online Journal of Educational Technology. january 2014 Vol 13 issue 1 (2014)

[12] Yunika Lestari dkk : Peningaktan Hasil Belajar dan Kemandirian Belajar Metode Statistika Melalui Pembelajaran Blended Learning. Jurnal Al-Jabar: Jurnal Pendidikan Matematika Vol. 8, No. 2, 2017, Hal 155 - 164 (2017) 